Provided for non-commercial research and education use. Not for reproduction, distribution or commercial use.

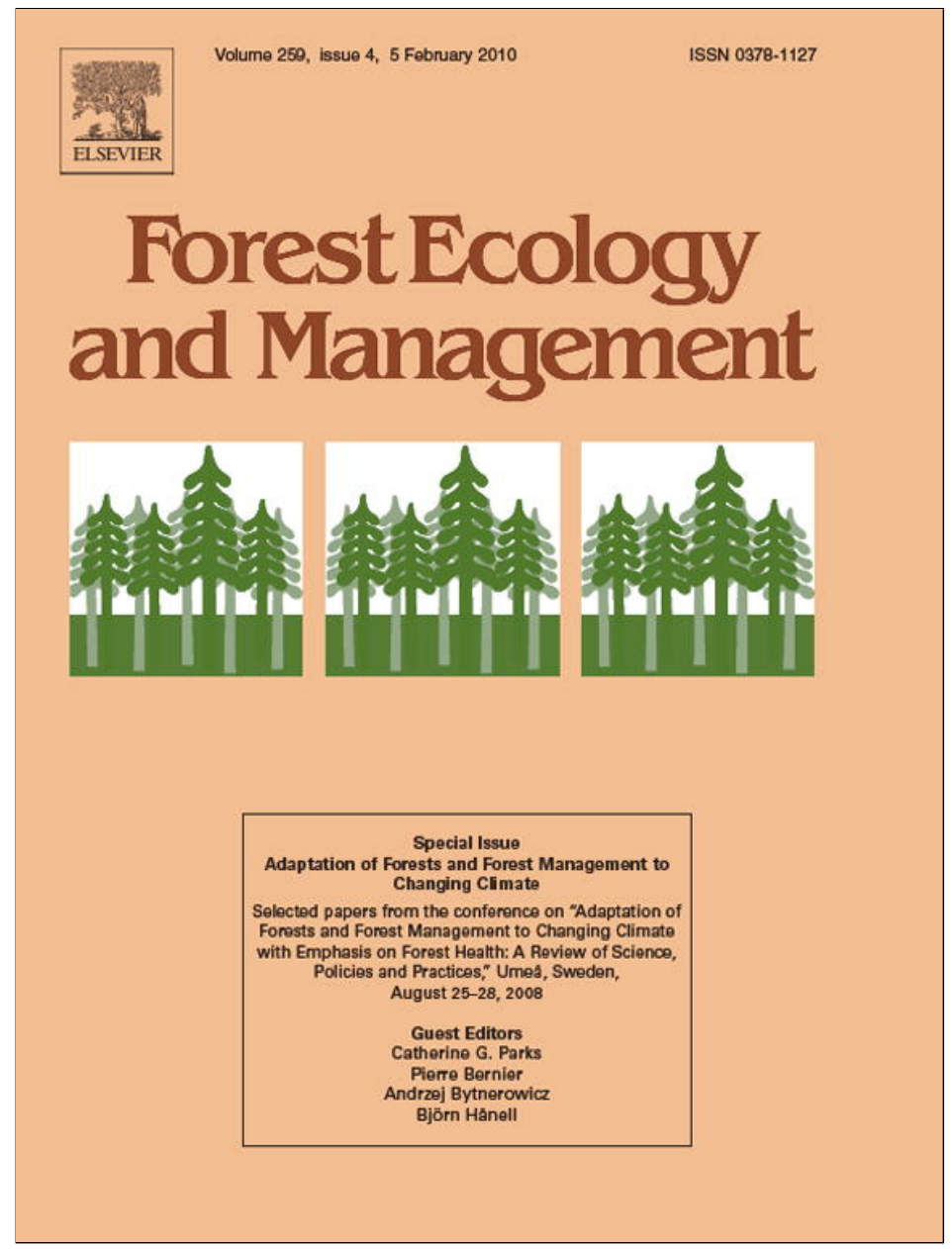

This article appeared in a journal published by Elsevier. The attached copy is furnished to the author for internal non-commercial research and education use, including for instruction at the authors institution and sharing with colleagues.

Other uses, including reproduction and distribution, or selling or licensing copies, or posting to personal, institutional or third party websites are prohibited.

In most cases authors are permitted to post their version of the article (e.g. in Word or Tex form) to their personal website or institutional repository. Authors requiring further information regarding Elsevier's archiving and manuscript policies are encouraged to visit:

http://www.elsevier.com/copyright 


\title{
Climate change impacts, adaptive capacity, and vulnerability of European forest ecosystems
}

\author{
Marcus Lindner ${ }^{\mathrm{a}, *}$, Michael Maroschek ${ }^{\mathrm{b}}$, Sigrid Netherer ${ }^{\mathrm{c}}$, Antoine Kremer ${ }^{\mathrm{d}}$, Anna Barbati ${ }^{\mathrm{e}}$ \\ Jordi Garcia-Gonzalo ${ }^{\mathrm{a}, 1}$, Rupert Seidl ${ }^{\mathrm{b}}$, Sylvain Delzon ${ }^{\mathrm{d}}$, Piermaria Corona ${ }^{\mathrm{e}}$, Marja Kolström ${ }^{\mathrm{a}}$, \\ Manfred J. Lexer ${ }^{\mathrm{b}}$, Marco Marchetti ${ }^{\mathrm{e}}$ \\ ${ }^{a}$ European Forest Institute (EFI), Torikatu 34, 80100 Joensuu, Finland \\ ${ }^{\mathrm{b}}$ Institute of Silviculture, Department of Forest- and Soil Sciences, University of Natural Resources and Applied Life Sciences (BOKU) Vienna, \\ Peter Jordan Strasse 82, 1190 Wien, Austria \\ ${ }^{\mathrm{C}}$ Institute of Forest Entomology, Forest Pathology and Forest Protection, BOKU, Vienna, Austria \\ d INRA - UMR Biodiversité Gènes et Communautés, Equipe de Génétique, France \\ ${ }^{\mathrm{e}}$ Italian Academy of Forest Sciences, Italy
}

\section{A R T I C L E I N F O}

\section{Article history:}

Received 2 February 2009

Received in revised form 26 August 2009

Accepted 15 September 2009

\section{Keywords:}

Climate change impacts

Adaptive capacity

Forestry

Vulnerability

Regional differences

\begin{abstract}
A B S T R A C T
This study compiles and summarizes the existing knowledge about observed and projected impacts of climate change on forests in Europe. Forests will have to adapt not only to changes in mean climate variables but also to increased variability with greater risk of extreme weather events, such as prolonged drought, storms and floods. Sensitivity, potential impacts, adaptive capacity, and vulnerability to climate change are reviewed for European forests. The most important potential impacts of climate change on forest goods and services are summarized for the Boreal, Temperate Oceanic, Temperate Continental, Mediterranean, and mountainous regions. Especially in northern and western Europe the increasing atmospheric $\mathrm{CO}_{2}$ content and warmer temperatures are expected to result in positive effects on forest growth and wood production, at least in the short-medium term. On the other hand, increasing drought and disturbance risks will cause adverse effects. These negative impacts are very likely to outweigh positive trends in southern and eastern Europe. From west to east, the drought risk increases. In the Mediterranean regions productivity is expected to decline due to strongly increased droughts and fire risks.

Adaptive capacity consists of the inherent adaptive capacity of trees and forest ecosystems and of socio-economic factors determining the capability to implement planned adaptation. The adaptive capacity in the forest sector is relatively large in the Boreal and the Temperate Oceanic regions, more constrained by socio-economic factors in the Temperate Continental, and most limited in the Mediterranean region where large forest areas are only extensively managed or unmanaged.

Potential impacts and risks are best studied and understood with respect to wood production. It is clear that all other goods and services provided by European forests will also be impacted by climate change, but much less knowledge is available to quantify these impacts. Understanding of adaptive capacity and regional vulnerability to climate change in European forests is not well developed and requires more focussed research efforts. An interdisciplinary research agenda integrated with monitoring networks and projection models is needed to provide information at all levels of decision making, from policy development to the management unit.
\end{abstract}

(c) 2009 Elsevier B.V. All rights reserved.

\section{Introduction}

The human influence on the earth's climate is becoming more and more obvious. Climate observations prove the existence of a

\footnotetext{
* Corresponding author. Tel.: +358 107734340 .

E-mail address: marcus.lindner@efi.int (M. Lindner).

${ }^{1}$ Current address: Centro de Estudos Florestais, Instituto Superior de Agronomia, Technical University of Lisbon, Portugal.
}

global warming trend: global average temperature has increased by $0.8^{\circ} \mathrm{C}$ since 1900 (Hansen et al., 2006) and the 12 hottest years observed globally since 1880 all occurred between 1990 and 2005 . The European heat wave of 2003 was a drastic demonstration of the extent of impacts we need to expect more often in the future (Schär and Jendritzky, 2004; Ciais et al., 2005). Latest climate change scenario projections for Europe suggest that by 2100 temperatures will increase between about $2{ }^{\circ} \mathrm{C}$ in Ireland and the UK, up to about $3{ }^{\circ} \mathrm{C}$ in central Europe and $4-5{ }^{\circ} \mathrm{C}$ in the northern 
Boreal and parts of the Mediterranean regions (Christensen et al., 2007). Atmospheric $\mathrm{CO}_{2}$ concentration in 2100 is projected to increase to at least $486 \mathrm{ppm}$ (in some scenarios even beyond $1000 \mathrm{ppm}$ ) compared to the pre-industrial concentration of 280 ppm (Nakicenovic et al., 2000).

Forests are particularly sensitive to climate change, because the long life-span of trees does not allow for rapid adaptation to environmental changes. Associated with climate change there are several factors affecting forest ecosystems, which can act independently or in combination. Two decades of research have significantly improved our understanding of these basic impact factors.

Rising concentrations of $\mathrm{CO}_{2}$ in the atmosphere increase photosynthesis rates, but vary with plant nitrogen status and species (Saxe et al., 1998; Norby et al., 1999; Ainsworth and Long, 2005). For example, mature Fagus sylvatica and Quercus petratea responded more than Carpinus betulus, Prunus avium, and Tilia platyphyllos in a central European free air enrichment experiment (Asshoff et al., 2006). Tree growth rate might not increase proportionally with increase in photosynthesis because of other limiting factors such as nutrient availability (Hungate et al., 2003; Luo et al., 2004). Increased atmospheric $\mathrm{CO}_{2}$ induces a partial closure of stomata reducing water loss by transpiration. This results in an increase in the ratio of carbon gain to water loss, i.e. the water use efficiency at the leaf and whole stand level increases (Field et al., 1995; Picon et al., 1996). In addition, increased allocation of carbon to root growth may enable plants to exploit soil water in a deeper and larger range of soil hence ameliorating the negative effects of water stress and better adapting to a waterlimited environment (Wullschleger et al., 2002).

Other changes in the chemical atmospheric environment affecting tree growth include tropospheric and ground-level concentrations of ozone, which may increase drought stress in trees (McLaughlin et al., 2007) and reduce tree biomass under current ambient compared to pre-industrial concentrations (Wittig et al., 2009). Also atmospheric nitrogen deposition has been a major factor influencing forest growth and other ecosystem characteristics over the last decades (Magnani et al., 2007; Kahle et al., 2008). Both ozone and nitrogen deposition affect tree physiology, carbon allocation and plant interactions, resulting in complex interactions with other climatic impact factors such as drought (e.g. Matyssek et al., 2006).

Effects of increases in temperature will differ with location, because bioclimatic zones in Europe differ in their limitations for forest production. An increase in temperature alone would be beneficial for boreal (Kellomäki and Wang, 1996; Briceño-Elizondo et al., 2006) and temperate conditions (Saxe et al., 2001), but interaction with other climate or site related factors can alter the response. Higher temperatures extend the growing season and may increase photosynthesis particularly in the northern latitudes. However, in other regions - where water availability restricts productivity - detrimental effects are possible, especially if the precipitation does not increase or shifts to the winter season, as projected e.g. for the Mediterranean areas (Loustau et al., 2005). Climate variability is particularly important in connection with changes in precipitation, because extreme events such as extended droughts have much more drastic consequences on tree growth and survival than gradual changes in average climate conditions (Fuhrer et al., 2006). Because trees are obviously adapting to the local average water availability (Kahle, 1994), extreme events cause growth responses across site conditions (Granier et al., 2007). Water limitation is expected to increase from the Temperate Oceanic to the Temperate Continental and the Mediterranean zones. In combination with increases in temperature this could lead to more droughts, especially in the Mediterranean and Temperate Continental zone. In these areas heat is often a stress factor. The optimum temperature for net photosynthesis rarely exceeds $30{ }^{\circ} \mathrm{C}$ for major European tree species. Thus, at high temperatures photorespiration is stimulated while photosynthesis is inhibited (Rennenberg et al., 2006).

The changes in climate will also have associated consequences for biotic (frequency and consequences of pest and disease outbreaks) and abiotic disturbances (changes in fire occurrence, changes in wind storm frequency and intensity) with strong implications for forest ecosystems.

Population dynamics and occurrence of exothermic organisms, such as insect herbivores, and the pathogenicity of fungal diseases will be strongly influenced by altered environmental conditions. However, the consequences for certain species will differ with geographic regions and the extent of climatic change. Both, positive responses of insect populations, such as increased development rate, increased chance of survival and reproductive potential and negative effects like decreased growth rate and reduced fecundity are to be expected (Hunter, 2001; Bale et al., 2002; Huberty and Denno, 2004). Climate change will impact frequencies of pest outbreaks (Williams and Liebhold, 1995; Volney and Fleming, 2000) and the sporulation and colonisation success of fungal pathogens (Ayres and Lombardero, 2000; Desprez-Loustau et al., 2006), and may not only promote shifts and expansions, but also contractions of distributional ranges for various herbivore and pathogen species (Cannon, 1998; Parmesan, 2006; Rouault et al., 2006).

Main abiotic disturbances in Europe are fire, wind, flooding and drought, all of which may be affected by climate change (Flannigan et al., 2000; Fuhrer et al., 2006; Moriondo et al., 2006). In the period 1950-2000, an annual average of 35 million $\mathrm{m}^{3}$ wood was damaged by disturbances (i.e. $8 \%$ of total fellings in Europe); storms were responsible for $53 \%$ of the total damage and fire for 16\% (Schelhaas et al., 2003). The years 2003 and 2007 demonstrated that forest fires may be substantially more devastating when large scale droughts prevail. Since 1990, several storms have caused large damage in European forests, resulting in yield reduction of recoverable timber, increased costs of unscheduled cuttings, problems in forestry planning, and, as recently shown, considerable carbon releases (Lindroth et al., 2009). Also flooding events are expected to occur more frequently with consequences on dynamics of riparian tree species and flood-prone areas (Glenz et al., 2006; Kramer et al., 2008).

These different impact factors will affect European forests, however severity of impacts on forest goods and services will depend on the regional situation and the specific changes in climate. Vulnerability to climate change also depends on the ability of natural ecosystems and society to cope with the impacts (Schröter et al., 2005). While many studies have investigated potential impacts of climate change, much less attention has been given to the adaptive capacity in the forest sector and few studies have assessed vulnerability of forestry to climate change. The regional context is important, as impacts can be both positive and negative and ability and strategies to cope with climate change impacts may differ. In this study we reviewed the existing knowledge about potential climate change impacts in different European forest regions. We analysed adaptive capacity, discuss our current understanding of regional differences in vulnerability to climate change and point out needs for further research.

\section{Methods}

\subsection{Concepts and terms used}

The concepts of impact, vulnerability, risk and adaptation are not clearly defined and interpretation of terms by scientific groups or policy makers can be quite different, which may lead to fuzzy or 


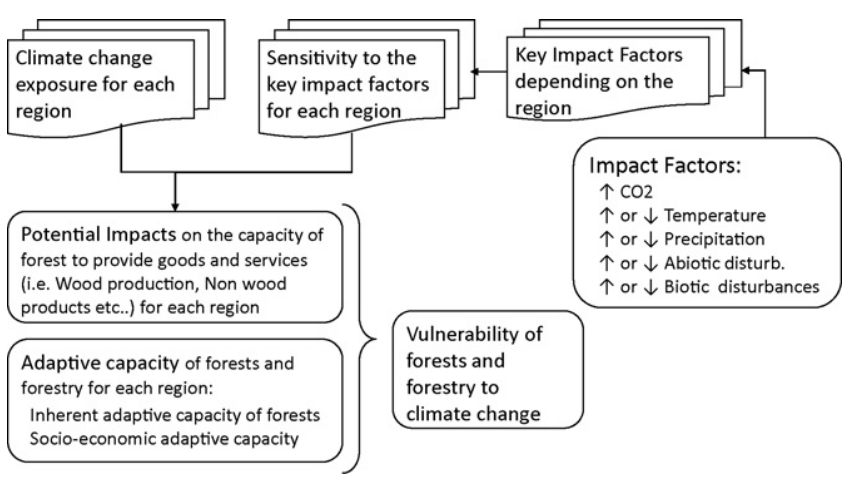

Fig. 1. Scheme of the approach followed to assess the climate change impacts and vulnerability in European forests.

even false expectations and responses (OECD, 2006). In this study, the methodological approach shown in Fig. 1 was adopted, using the following terms:

- Impact factors are climatic, physical, and biological variables that are influenced by climate change and cause the impacts in the system.

- Exposure specifies the projected change of climate that is affecting the system.

- Sensitivity describes the degree to which a system is affected, either adversely or beneficially. The effects of climate change may be direct (e.g. changes in forest growth in response to a change in temperature or precipitation) or indirect (e.g. damages caused by an increase in the frequency of fires or a new biotic pest species).

- Impacts are the consequences of climate change that are likely to affect forest goods and services and forestry activities, as a function of exposure and sensitivity to changes.

- Adaptive capacity describes the ability of a system to adapt to changes in climate.

- Inherent adaptive capacity summarizes the evolutionary mechanisms and processes that permit tree species to adjust to new environmental conditions.

- Socio-economic adaptive capacity is the ability of human sectors, like forestry, to implement planned adaptation measures.

- Vulnerability can be defined as the degree to which a system is susceptible to be affected by adverse effects of climate change. The vulnerability of a given system is a function of the climate variation to which this system is exposed (exposure), its sensitivity (together resulting in impacts on goods and services), and its adaptive capacity.

- Risk is the potential adverse outcome of a particular impact.

- Opportunity is the potential beneficial outcome of a particular impact.

\subsection{Scope of the analysis}

The study covered direct and indirect impacts on the capacity of forests to provide economic, social and ecological services. The following goods and services were studied (when information was available):

i) wood production,

ii) any non-wood forest products (e.g. berries, mushrooms),

iii) carbon sequestration,

iv) biodiversity,

v) recreation,

vi) protective functions.

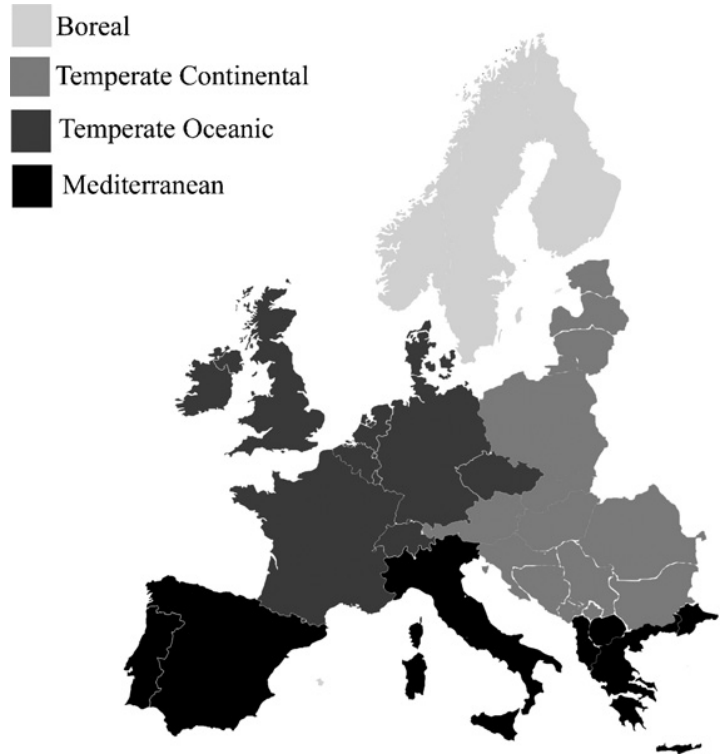

Fig. 2. Principle allocation of European countries to bioclimatic zones. Many countries span across different zones and results of neighbouring zones should also be considered.

\subsection{Bioclimatic zonation}

Climate change sensitivity and exposure differ between bioclimatic zones and forest types in Europe. The study thus analysed climate change impacts separately for different bioclimatic regions/forest types. The bioclimatic map of Europe was used as reference classification (Rivas-Martínez et al., 2004); the top level hierarchy of this bioclimatic classification are four macrobioclimates delimited by means of current climatic parameters and vegetation characteristics. European forests cover three major macrobioclimates: Boreal, Temperate and Mediterranean. Each of them and their subordinate units or bioclimates is represented by a characteristic group of forest formations. We divided the Temperate macrobioclimate to reflect the effect of continentality and used four bioclimatic zones to structure this review - Boreal, Temperate Oceanic, Temperate Continental and Mediterranean. In addition mountainous regions were separately considered to better represent mountain specific processes and impacts. Fig. 2 shows the simplifying assignment of European countries to bioclimatic zones.

\section{Sensitivity and potential impacts of climate change in bioclimatic regions}

In the following sections, for each region the latest regional climate change projections of the Intergovernmental Panel on Climate Change until the end of the 21st century (Christensen et al., 2007), the regional sensitivity to climate change and the most important potential impacts are summarized.

\subsection{Boreal zone}

\subsubsection{Exposure}

Temperatures are projected to increase by $3.5-5{ }^{\circ} \mathrm{C}$ with higher increase during winter $\left(4-7^{\circ} \mathrm{C}\right)$ than in summer $\left(3-4{ }^{\circ} \mathrm{C}\right)$. Significant increases in yearly precipitation (up to 40\%) are predicted. Winters are projected to become wetter.

\subsubsection{Sensitivity}

The productivity of boreal forests is limited by short growing seasons, low summer temperatures and short supply of nitrogen 
(Kellomäki et al., 1997; Mäkipää et al., 1998). The projected change in temperature will prolong the growing season, enhance the decomposition of soil organic matter and increase the supply of nitrogen (Kirschbaum, 1995). This may further enhance forest growth, consequent timber yield and the accumulation of carbon in the biomass (Kellomäki and Väisänen, 1997). However, in areas with reduced precipitation in the southern Boreal, the potential increase in productivity could be reduced or offset due to water limitations (Briceño-Elizondo et al., 2006). Milder winters may reduce winter hardening in trees, increasing vulnerability to frost e.g. in oak stands in south-western Finland (Hänninen, 2006). Warmer and wetter winters negatively affect logging operations on wet soils. Tree species distributions may change and broadleaved deciduous trees are expected to expand northwards. Forest damage by wind and snow are projected to increase (Peltola et al., 2000).

Because of harsh climate, the Boreal zone lies beyond the distribution range of various insect herbivores - a situation which could be drastically changed by increasing winter and summer temperatures. For instance, northward expansions of Lymantria dispar and L. monacha (Vanhanen et al., 2007) are expected, as well as range expansion and increased frequencies of mass propagation for Neodiprion sertifer (due to decreased winter egg mortality; Virtanen et al., 1996; Veteli et al., 2005) and Ips typographus (triggered by storm events and warm and dry summers; Okland and Bjornstad, 2003; Wermelinger, 2004). Longer growing seasons and higher temperatures will also benefit fungal diseases, such as Heterobasidion parviporum and H. annosum (Thor et al., 2005; Mattila and Nuutinen, 2007), whereas organisms especially adapted to severe environmental conditions (e.g. Gremmeniella abietina) can be less virulent with higher summer temperatures (Bernhold, 2008).

\subsubsection{Potential impacts on forest goods and services}

Garcia-Gonzalo et al. (2007b) projected for a forest unit in Central Finland an increase in stand growth by $22-26 \%$, resulting in $8-22 \%$ increased timber yield, depending on the climate scenario and the species. Projected growth enhancements are more than $50 \%$ larger in northern compared to southern Finland (BriceñoElizondo et al., 2006). Another study found increased net primary production (NPP) by $5-27 \%$ for coniferous stands, being less for a Scots pine stand growing in Norway compared to a continental climate in central Sweden and eastern Finland (Bergh et al., 2003).

Kauserud et al. (2008) observed that mushroom fruiting has changed considerably in Norway with an average delay in fruiting since 1980 of 12.9 days. The changes differ strongly between species, resulting in a more compressed fruiting season. Winter warming and increased summer precipitation reduced flowering and berry production in Vaccinium species in northern Sweden (Phoenix et al., 2001; Bokhorst et al., 2008). However, the relationships between yield of berries and climate variables are not fully understood (Wallenius, 1999).

The forest carbon balance will be strongly determined by forest management, as most of the additionally sequestered carbon will be removed in intensively managed forest systems. Compared to current climatic conditions, Garcia-Gonzalo et al. (2007a) simulated around 1\% higher total carbon (C) stock in the forest ecosystem, whereas the mean increase in total $C$ in timber yield was up to $12 \%$. Under scenarios with high temperature increase, $C$ could be released from the soil (e.g. Mäkipää et al., 1999). The feedback between carbon (C) and nitrogen (N) turnover plays an important role that needs to be more clearly understood to improve estimates of $C$ sequestration in boreal forest ecosystems (Svensson et al., 2008).

Broadleaved deciduous trees may expand their potential distribution ranges into the boreal forests, consequently increasing tree species and functional diversity (Thuiller et al., 2006). Woody vegetation is expected to spread into tundra at higher latitudes and higher elevations (Grace et al., 2002), threatening some Artic animal and plant specialists with extinction (Callaghan et al., 2004; Aitken et al., 2008).

Nature-based tourism and outdoor recreation are directly affected by changes in climate (Saarinen and Tervo, 2006). In southern Finland, opportunities for snow-related activities are expected to decline, whereas northern Finland could have a competitive advantage compared to winter tourism destinations in central Europe.

\subsection{Temperate Oceanic zone}

\subsubsection{Exposure}

Annual mean temperature increases are projected to be 2.5$3.5^{\circ} \mathrm{C}$, except for the UK and Ireland with $2-3{ }^{\circ} \mathrm{C}$. Summers are likely to be dryer and hotter (up to $4{ }^{\circ} \mathrm{C}$ increase). Extreme events such as storms, floods and droughts are projected to become more harmful.

\subsubsection{Sensitivity}

Temperature increase will have a positive impact on forest growth in northern and western parts (i.e. less water-limited areas) and a negative impact on southern and eastern parts (i.e. water-limited regions). In the southern parts of the region droughts are the main constraint of forest growth and productivity. Temperature increase may have strong impacts on forest productivity and the competitive relationships between tree species (Lasch et al., 2002b). Thuiller et al. (2006) projected a reduction in the number of species in the Atlantic areas. In large areas of western and central Europe, indigenous conifers may be replaced by more competitive deciduous trees (Maracchi et al., 2005). The most important effects of climate change on temperate forests will probably be mediated through changes in disturbance regimes such as storms (Thürig et al., 2005; Schutz et al., 2006), insects and pathogens. Temperature increase associated with a decrease in precipitation will probably implicate accelerated development and lowered mortality rates for various species of insect herbivores. As a result, the incidence of mass outbreaks of pest species will rise, e.g. of forest defoliators such as Elatobium abietinum in the UK (Westgarth-Smith et al., 2007). Prolonged and warmer vegetation periods will especially enhance the development of bark beetles, allowing for the establishment of additional generations and multiplying population densities. Range expansions and range shifts are to be expected for pest insects such as $L$. dispar, L. monacha (Karolewski et al., 2007), Thaumetopoea pityocampa, (Battisti et al., 2005; Robinet et al., 2007), and also for termophilic pathogen species, such as Biscogniauxia mediterranea (Desprez-Loustau et al., 2007). The potential damage of fungal diseases present in a latent form in wide areas (e.g. B. mediterranea, Diplodia pinea) will likely be exacerbated by the decrease in precipitation, as endophytes may turn to pathogens in droughtstressed trees.

\subsubsection{Potential impacts on forest goods and services}

Most of the region is projected to benefit from increased growth rates under expected future climate conditions and thus also wood production tends to increase (Eggers et al., 2008). Negative impacts may occur especially in the southern and eastern parts of the region where climate has a noticeable Mediterranean or continental influence. Potentially devastating negative impacts may occur due to extreme climatic events and enhanced disturbances (both biotic and abiotic). Consequently, the share of unscheduled fellings and salvage cuts after stand destructing disturbances is likely to increase. In northern France, forest productivity is 
expected to be enhanced by climate change, with an increasing trend from west to east. In the southwestern Atlantic region, productivity will be reduced by climate change to an increasing degree from west to east (Loustau et al., 2005). For Germany, scenarios with increases in precipitation resulted in up to a $7 \%$ increase in productivity of three out of four main species, whereas under a drier scenario all species were projected to decline in productivity by $-4 \%$ to $-16 \%$ (Lasch et al., 2002a).

Little evidence is available regarding impacts on non-wood forest products. Gange et al. (2007) analysed autumnal fruiting patterns of macrofungi over 56 years and found that average first fruiting date of 315 species was advanced, while last fruiting date was delayed. Opportunities were identified under climate change through increased potential walnut production (Hemery and Russell, 2006).

Carbon sequestration is likely to benefit from increased tree growth and productivity in most of the Temperate Oceanic region (Vetter et al., 2005; Lettens et al., 2008), at least in the short to medium term (Eggers et al., 2008). However, the carbon balance may be negatively impacted by more frequent disturbances (Lindroth et al., 2009).

Projected impacts on biodiversity include thermophilic plant species becoming more common, while cold-tolerant species decline (Reid, 2006). Different species groups might respond differently to changing conditions. As a result of climate change, epiphytic species appear to be increasing, but in contrast, many terricolus species are declining (Aptroot and van Herk, 2007).

\subsection{Temperate Continental zone}

\subsubsection{Exposure}

The annual mean temperature increase is projected to be in the order of $3-4{ }^{\circ} \mathrm{C}$ and up to $4.5^{\circ} \mathrm{C}$ in the Black Sea Region. Annual mean precipitation is expected to increase by up to $10 \%$ mainly in winter, while summer precipitation is projected to decline in several areas (up to $-10 \%$ ).

\subsubsection{Sensitivity}

In this bioclimatic zone, forest production is mainly constrained by water availability (Maracchi et al., 2005) and decreasing annual precipitation or changes in inter- and intra-annual distribution will result in stronger water limitations than today. Production is likely to decrease at sites vulnerable to water stress and to increase where the increased evaporative demand under the elevated temperature is balanced by an increase in precipitation. Impacts on individual species can be either positive or negative, depending on site conditions and regional climatic changes. F. sylvatica is projected to face severe problems under increasing temperatures (Geßler et al., 2007). Milder winters may reduce winter hardening in trees, increasing their vulnerability to frost (Hänninen, 2006). Fire danger is likely to increase (Moriondo et al., 2006). The projected considerable increase of temperature will strongly impact population dynamics and distribution of exothermic organisms and probably trigger outbreaks of certain pest insects. Even high increases in average temperature are expected to have positive effects for $L$. dispar (Vanhanen et al., 2007). Hlásny and Turcány (2009) expect altitudinal range shifts and a doubling of outbreak areas by 2015 compared to 1951-1980 for Slovakia. Populations of $I$. typographus will benefit from a fully developed second generation; in certain regions even a third generation. Outbreaks of bark beetles (e.g. I. typographus and Pityogenes chalcographus) will generally be fuelled by abiotic disturbances such as wind throw or drought (Wermelinger, 2004). Drought stress of trees will predispose forests also to infestation by other insect herbivores and fungal diseases, such as Armillaria spp. (Wargo and Harrington, 1991). Tree dieback due to Armillaria is also reported in association with oak decline, together with an assortment of fungal pathogens (e.g. Phytophthora quercina), during periods of soil water deficits (Balci and Halmschlager, 2003).

\subsubsection{Potential impacts on forest goods and services}

By the end of the century net primary production (NPP) of conifers is likely to decrease in continental and central Europe due to water limitations (Lexer et al., 2002). Beyond a temperature increase of approximately $1{ }^{\circ} \mathrm{C}$ (with no changes in precipitation) impacts may become widespread and severe, rendering lowelevation sites unsuitable for Picea abies as a crop species (Lexer et al., 2002). A study from a continental region in the north-eastern German lowlands projected decreases in wood production in the order of $-10 \%$ (Lasch et al., 2002a).

In Slovenia, at the northern climatic limit of olive trees, frost occurrence is projected to further restrict the distribution range of the species (Ogrin, 2007).

Carbon sequestration may increase in the short to mid term, especially in the northern parts of the region (Vucetich et al., 2000; Reed and Nagel, 2003), but towards the end of the century, forests could turn into a source of carbon (Eggers et al., 2008). While targeted management has the potential to increase carbon sequestration disturbances might reduce $C$ stocks (Seidl et al., 2008a,b).

\subsection{Mediterranean zone}

\subsubsection{Exposure}

Annual mean temperatures are projected to increase in the order of $3-4{ }^{\circ} \mathrm{C}\left(4-5{ }^{\circ} \mathrm{C}\right.$ in summer and $2-3{ }^{\circ} \mathrm{C}$ in winter $)$. Yearly rainfall is expected to drop by up to $20 \%$ of current annual precipitation (up to $50 \%$ less in summer), whereas winter precipitation is expected to increase. Changes in frequency, intensity, and duration of extreme events are likely to result in more hot days, heat waves, heavy precipitation events, and fewer cold days.

\subsubsection{Sensitivity}

Rising temperatures and the projected decrease in rainfall will magnify drought risk. Photosynthesis will decrease during hot spells and biomass growth and yield are expected to decline. Even drought-adapted ecosystems are influenced by drought (Rambal et al., 2003) and increased drought is likely to lead to reduced plant growth and primary productivity (Ogaya et al., 2003) and altered plant recruitment (Lloret et al., 2004). Over the last 50 years, a temperature increase of $1.4{ }^{\circ} \mathrm{C}$ (with stable annual precipitation) has already resulted in progressive replacement of European beech (F. sylvatica) by Holm oak (Quercus ilex) in the higher elevations of the Pyrenees (Peñuelas and Boada, 2003). The main causes were reduced recruitment and increasing defoliation of beech. Moreover, other studies show that long-term drought stress reduced the productivity of beech forests at the southern range edge (Jump et al., 2006). Prolonged droughts and hot spells will further aggravate forest fire risks. Forest fires will become an even larger threat to Mediterranean forestry and human well-being in rural areas (Moriondo et al., 2006). Frequent fires can increase soil erosion due to enhanced hydrophobicity (Certini, 2005) and reduced plant regeneration (Delitti et al., 2005). In dry areas, desertification may accelerate. Distributional shifts of insect populations are probable (Battisti, 2004; Hodar and Zamora, 2004) and highly thermophilic pathogen species are likely to become more virulent. Typical components of the endophytic microflora inhabiting Mediterranean tree species, such as $B$. mediterranea on Quercus spp. and D. pinea on Pinus spp. may develop rapidly in case of water stressed host trees and cause 
sudden forest dieback. Such shifts from latency to pathogenic stage in case of fitting environmental conditions (drought) may pose a considerable threat to southern forests under a changing climate (Desprez-Loustau et al., 2006; Maresi et al., 2007).

\subsubsection{Potential impacts on forest goods and services}

Wood production is expected to decline, as the negative effect of the increase in temperature will be likely not compensated by the positive effects of increasing atmospheric $\mathrm{CO}_{2}$ concentration. Scots pine (Pinus sylvestris) has increased stem growth during the 20th century in Catalonia, but increasing temperatures had already negative impacts on drier sites (Martínez-Vilalta et al., 2008). The increased fire risk will further reduce wood production and decrease timber values in burned areas.

The production of non-wood products - particularly important in the Mediterranean region - will also be negatively affected by climate change. There is a clear relationship between mushroom production and rainfall (Martínez de Aragón et al., 2007). It can be inferred that a decrease in precipitation with increased droughts will likely reduce mushroom production.

Carbon sequestration rates and the net carbon balance will be strongly influenced by disturbances, especially by projected increases in frequency and intensity of forest fires and by the negative impacts of drought on forest growth and productivity.

The forecasted global warming and fire increase may trigger irrecoverable biodiversity losses and shifts in vegetational composition within a few decades or centuries at most. Fire and drought-sensitive vegetation types seem particularly threatened by large-scale displacement (Colombaroli et al., 2007).

\subsection{Mountainous regions}

\subsubsection{Exposure}

European mountain regions may experience somewhat higher increases in temperature compared to the surrounding regions. In the Alps, for instance, temperature increases twice as the global average were observed over the last century (Auer et al., 2007). Changes in precipitation amount and patterns are subject to high uncertainty and will be strongly determined by local geomorphology.

\subsubsection{Sensitivity}

Considering the high heterogeneity in geomorphology, microclimate and soil formation that are characteristic for mountain areas, climate change sensitivities strongly vary at local and regional scales. Tree growth is expected to decrease on waterlimited sites due to increasing drought stress, particularly in Mediterranean mountain ranges as well as lower elevation foothills and dry valleys of the Alps and Carpathians (Rebetez and Dobbertin, 2004; Jump et al., 2006). Sites currently limited by temperature (i.e. at higher elevation) can generally expect growth increases as a result of warming (Tardif et al., 2003; Bolli et al., 2007; Büntgen et al., 2007). Furthermore, disturbance regimes in mountain areas are expected to be substantially affected by changes in climate. Whereas historically limited by harsh environmental conditions, large areas of coniferous forests in the European temperate mountain ranges will become an increasingly suitable habitat for poikilotherm insects (e.g. I. typographus, Seidl et al., 2009)). In the last 15 years increasing damage by $I$. typographus and $P$. chalcographus has already been observed e.g. in the Alps (Krehan and Steyrer, 2004; Engesser et al., 2005) due to enhanced multivoltinism (Bale et al., 2002; Baier et al., 2007; Hlásny and Turcány, 2009), but also triggered by large wind throw events (e.g. Viviane in 1990, Wiebke in 1992). Altitudinal range expansions due to warmer temperatures have also been documented for other insect pests, e.g. T. pityocampa in the North Italian Alps (Battisti et al., 2006). Forest fires, particularly difficult to combat in complex mountainous terrain, are likely to increase in the Pyrenees and become a relevant disturbance factor also in temperate mountain ranges (Schumacher and Bugmann, 2006). Overall, the ecosystem dynamics of European mountain forests will be distinctly affected by climate change, changing plant species competitivity and subsequent distribution, structure and composition of mountain forests (Lexer et al., 2002; Skvarenina et al., 2004). In particular the highly temperature sensitive tree line ecotone will respond to warming by an upward shift where suitable micro-sites are available (Camarero and Gutierrez, 2004; Bolli et al., 2007; Peñuelas et al., 2007). Alleviated stress from snow-dependant fungi such as Phacidium infestans, Herpotrichia juniperi, G. abietina (Nierhaus-Wunderwald, 1996; Senn, 1999) might contribute to this trend.

\subsubsection{Potential impacts on forest goods and services}

Timber production as well as carbon sequestration will be significantly affected by changes in productivity and intensified disturbance regimes (Zierl and Bugmann, 2007; Seidl et al., 2008a). The patterns and distribution of these impacts will be strongly related to the steep environmental gradients of mountainous areas. In many mountain forests climate change will broaden the silvicultural decision space, e.g. due to an increasing number of climatically suitable broadleaved species in montane and subalpine vegetation belts of the Alps and Carpathians.

The provision of drinking water is an important ecosystem service of mountain forests. Intensified large-scale disturbances like forest fires, wind throws and pest outbreaks may lead to changes in runoff as well as in percolation and water quality (i.e. intensified erosion and increased suspended loads). Moreover, water quality will be negatively influenced by intensified decomposition of litter and humus due to extensive canopy openings following disturbances and increased temperatures, leading to leaching of nitrate (Jandl et al., 2008).

Vital for densely populated mountain areas is the protective function of forests against natural hazards like flooding, debris flow, landslide, rock fall and avalanches. Climate change might alter frequency and magnitude of these gravitational processes, e.g. via changes in precipitation amounts and patterns, snow load, or frost-thaw cycles. The protective effect of forests will suffer strongly from intensified disturbance regimes (Schumacher and Bugmann, 2006). Yet a temperature-induced upward shift of the tree line will improve protection against natural hazards by stabilizing soils and erodible masses, reducing avalanche starting zones and dampening runoff peaks. For highly specialized alpine and nival plant communities such an upward shift of the tree line ecotone poses a substantial threat (Theurillat et al., 1998). In managed forests however, where human interventions are strongly affecting biodiversity, the increasing competitiveness of species-rich broadleaved forest communities may even promote overall biodiversity compared to prevailing conifer-dominated ecosystems (Kienast et al., 1998).

\section{Adaptive capacity in European forestry}

Adaptive capacity has two components: the inherent adaptive capacity of trees and forest ecosystems and the socio-economic factors determining the ability to implement planned adaptation measures.

\subsection{Inherent adaptive capacity}

The inherent adaptive capacity encompasses the evolutionary mechanisms and processes that permit tree species to adjust to new environmental conditions. Tree species have been exposed 
during their evolutionary history to long term "natural" environmental change, and have shown capability to respond and adapt to these changes. Translated in genetic terms, climate change represents a gradual directional environmental shift that is sporadically shaken by stochastic extreme events. Different evolutionary mechanisms in genetic adaptation have been identified and they are acting at different hierarchical levels: (i) at the individual level they include individual heterozygosity, acclimation and epigenetic responses; (ii) natural selection occurs at the population level; (iii) at the species level local adaptation is enhanced by gene flow and new sites are colonised; (iv) at the community level competition and facilitation among tree species take place and interspecific hybridization occurs.

Individual heterozygosity accounts for genetic diversity at a single tree level and has been observed e.g. in response to air pollution (Müller-Starck, 1988). Acclimation response over the lifetime of a tree has been observed e.g. for the gradual decrease of leaf stomatal density on a single birch tree over 50 years in response to increasing atmospheric $\mathrm{CO}_{2}$ content (Wagner et al., 1996). Many epigenetic responses have been documented in plants as a response to temporary, severe environmental or biotic stresses (Madlung and Comai, 2004). For instance, the "maternal effect" in $P$. abies showed that trees are influenced by the environmental conditions prevailing during the development of the embryo (Skrøppa et al., 1994). The timing of bud break in spring, leader shoot cessation in summer, bud set in autumn and the lignification of the annual ring are all advanced or delayed according to temperature during female reproduction. Recent studies indicated that in some cases environmentally induced epigenetic changes may be inherited by future generations (Bossdorf et al., 2008).

Local adaptation underlies natural selection, which drives populations towards higher fitness to meet environmental changes. Continuous shifts in gene frequencies or phenotypic values of traits are well documented through results of provenance tests (König, 2005).

Local adaptation at species level can be increased by "incoming genes" via pollen stemming from populations exhibiting higher fitness than the receiving population (Lenormand, 2002; Smouse and Sork, 2004). In the case of directional environmental changes towards higher temperature, it is likely that populations from more southern latitudes may constitute valuable pollen source populations in this respect.

Postglacial history of forest tree migration in Europe suggests that natural distribution range shifts are restricted, at maximum, to 10-70 km per century (Birks, 1989; Brewer et al., 2002), not taking into account migration barriers through land fragmentation.

Biotic interactions are recognised as one of the most important filters of community composition (Lortie et al., 2004). Competition may result in more negative species interactions under climate warming (Klanderud, 2005), whereas in cold arctic environments, positive interactions through facilitation may also buffer the effect of climate change on beneficiaries species (Wipf et al., 2006).

Limited knowledge is available on the pace of the evolutionary processes. Past seed dispersion data obtained by fossil pollen records suggest that the speed of future natural dispersion may not be able to keep up with the shift of bioclimatic envelopes of trees species (Solomon, 1997). Strong differences are anticipated between species having continuous distribution and species with scattered distribution, the former benefiting more from positive interactions between natural selection and gene flow. The rate of adaptive change may also be quite different between the leading edge and the rear end of species distributions. Populations at the northern and eastern limit will be at the leading front of range shifts and may benefit from immigrating genes via pollen flow from southern latitudes. At the rear edge, adaptation may be more constrained because populations are deprived of gene flow from "preadapted" populations.

Maintaining or improving the genetic adaptive capacity of populations and species is important to facilitate natural adaptation to climate change especially in the long term. However, understanding these mechanisms is crucial also in the short term, as inherent adaptive capacity can be supported with planned adaptation measures.

\subsection{Socio-economic adaptive capacity}

Socio-economic factors that determine adaptive capacity to climate change include economic development, technology and infrastructure, information, knowledge and skills, institutions, equity and social capital (McCarthy et al., 2001). In the ATEAM project (Schröter et al., 2005), a generic adaptive capacity index was calculated, but this index did not include individual abilities to adapt and thus underestimated the important social dimension of adaptive capacity (Adger et al., 2007). The socio-economic adaptation capacity related to the forest sector has rarely been analysed in EU27 up to now. Keskitalo (2008) pointed out that external factors such as globalisation and demands for rationalisation and profitability are constraining the adaptive capacity in the forestry sector. Economic viability in the context of limited resources was an important issue for most of the forest stakeholders interviewed in a case study in Northern Sweden. Relative to the huge contrast between more and less developed countries at global scale, socio-economic conditions are comparably similar within Europe. Nevertheless, there are significant differences in socio-economic conditions within the forest sector in Europe and these will affect the adaptive capacity to respond to climate change in forestry. Adaptive capacity in case study regions in Northern Sweden and Northern Finland was found to be much higher than in the neighbouring region in Northwest Russia (Lundmark et al., 2008).

Northern Europe is an area of intensive forest management. Forest sector development has been very dynamic in this region with many innovative technological developments, documenting a very high adaptive capacity. Natural resource conditions are very different in large parts of Southern Europe, where many forests are located on sites having low potential for environmentally sustainable wood production due to a combination of limiting factors (low site fertility, terrain steepness, high soil erosion risk). Social and environmental forest ecosystem services are far more important (e.g. biodiversity conservation, watershed protection, carbon sequestration, landscape beauty and recreation).

The lack of economic activity in forestry and of systems for the remuneration of forest social and environmental services are constraining adaptive capacity in Southern Europe, because adaptation would need to be implemented top down (i.e. by policy incentives or societal activities) with little support from forest owners and the forest sector. Forest ownership structures in general can also influence adaptive capacity. Management traditions and decision making structures are more variable in privately owned forests compared to large public forest holdings. Individual interests in forest management and preferences for management objectives as well as risk perception differ and this tends to enhance diversity in forest structures and silviculture. This diversity may support the inherent adaptive capacity as discussed in the previous section. On the other hand, small and fragmented privately owned forests are often poorly managed, constituting a barrier to efficient wood resource utilization and adaptive management practices. Forest co-operations and active support from public forestry administration are possible measures alleviating the constraints. But without them, adaptive capacity is likely to be smaller in regions with a big share of fragmented forest holdings. 
Availability or shortage of forest sector work force is another socio-economic factor that differs between regions. Together with the education level of forest workers, which is more or less closely related, this will also influence the adaptive capacity in the forest sector.

The adaptive capacity in the forest sector is relatively large in the Boreal and the Temperate Oceanic regions. In the Temperate Continental region adaptive capacity in the forest sector is more strongly affected by socio-economic constraints. Adaptive capacity is strongly limited in the Mediterranean region where large forest areas are only extensively managed or unmanaged. Complex terrain in mountain regions poses a considerable constraint to forest infrastructure and technology (e.g. road networks, harvesting machinery) which reduces adaptive capacities compared to more accessible lowland forests.

\section{Vulnerability to climate change in Europe - risks and opportunities}

Climate change is now recognised as one of the most serious challenges facing the world - its people, the environment and its economies. The changing climate is also a major challenge for EU forests and forestry. We reviewed the currently available literature on potential impacts of climate change on European forests. While sensitivities and the areas of climate risks and opportunities are increasingly well understood, a spatially stratified quantification of climate change effects is still widely missing. In general we expect that improved forest productivity in the Boreal region will create opportunities for increased utilization of forest resources in the mid to long term. However, reduced availability of timber due to inaccessibility of forest resources on wet soils outside the frost period will pose a threat to the industry. Extreme events such as storms, droughts, flooding, and heat waves are probably the most important threats in Temperate Oceanic regions. Drought risk is an important threat especially under water-limited conditions in Temperate Continental and the Mediterranean regions. The extreme forest fire risk is the largest threat in the Mediterranean region. For European mountain regions steep elevation gradients and increased spatial heterogeneity are superimposing these trends. While the relaxation of climatic limitations in high elevation areas offers opportunities for forest management, increasing disturbances might counteract and be detrimental, e.g. for the particularly important protective function of mountain forests.

Assessing potential impacts of climate change needs to consider general trends in climate variables, short-term climate variability, and the interactions with biotic and abiotic disturbances. Especially in northern and western Europe the increasing atmospheric $\mathrm{CO}_{2}$ content and warmer temperatures will result in positive effects on forest growth and wood production - at least in the short-medium term. On the other hand, increasing drought and disturbance risks will cause adverse effects. These negative impacts are very likely to outweigh positive trends in southern and eastern Europe. With more drastic changes in climate towards the end of the 21 st century, severe and wide ranging negative climate change impacts have to be expected in most European regions.

The regional review of climate change sensitivities and potential impacts revealed significant spatial asymmetry in systems understanding. A majority of climate change impact studies address the Boreal and parts of the Temperate region, whereas for example hardly any specific regional knowledge was found from southeastern Europe. The same holds for the strongly heterogeneous European mountain ranges, where a considerable number of studies focus on the European Alps while the knowledge base for the Carpathians and Pyrenees was distinctly less dense. Potential impacts and risks are best studied and understood with respect to wood production. It is clear that all other goods and services provided by European forests will also be impacted by climate change, but much less knowledge is available to quantify these impacts.

It needs to be emphasized that the reviewed climate change sensitivity and impact assessments still contain large uncertainties. Ecosystem responses to gradual changes are easier to project, but the effects of climate variability and extreme events are expected to be much more critical (Fuhrer et al., 2006), but also more difficult to model. Europe has been spared so far from devastating pest outbreaks, but the potential risk of high impact responses to different disturbances is increasing a lot under climate change.

It seems inevitable that European forestry will have to cope with significant adverse impacts of climate change, at least in the mid to long term. Reviewing our understanding of adaptive capacity reveals that natural mechanisms of inherent adaptive capacity are diverse and will support adaptation of forests to climate change. However, natural processes alone are too slow to cope with the projected rates of environmental change. For example, pollen dispersal distances facilitating gene flow from southern provenances are not of the same magnitude then the shift of isotherms and the associated bioclimatic envelopes of species (cf. Thuiller et al., 2008). Understanding of genetic adaptive processes is still evolving and no attempts have been made so far to quantify their potentials. However, from European biogeography it can be inferred that adaptive capacity is smallest at the rear edge of the forest biome, where only short-term adaptation and plasticity are able to counteract the threat of extirpation of forest species under less suitable climate conditions. There are considerable differences in socio-economic adaptive capacity within Europe and it is worrying that this is smallest in the Mediterranean region where the largest potential impacts are expected. Consequently, vulnerability to climate change is larger in that region compared to the rest of Europe.

Vulnerability can be defined as the degree to which a system is susceptible to be affected by adverse effects of climate change. The vulnerability of a given system is influenced by the climate variation to which this system is exposed, its sensitivity, and its adaptive capacity to respond to the potential impacts (Kelly and Adger, 2000; Füssel and Klein, 2006). The vulnerability of ecosystem goods and services to climate change was first assessed in Europe within the ATEAM project (Schröter et al., 2005; Metzger et al., 2008), where vulnerability was interpreted as "The degree to which an ecosystem service is sensitive to global change + the degree to which the sector that relies on this service is unable to adapt to the changes". The ATEAM assessment of vulnerability, risks and opportunities for European forests (Eggers et al., 2008) represents the state-of-the-art in this field, but it has clear limitations regarding (i) the climate scenarios that were available, (ii) a relatively coarse resolution of the results due to the aggregation level of regional forest inventory data, and (iii) the lack of consideration of adaptive capacity and planned adaptation in forest management. Metzger et al. (2008) linked forest assessment results with an adaptive capacity index calculated across Europe and concluded that vulnerability of the forest sector to climate change was rather low. However, due to the limitations listed above, this assessment has to be interpreted with caution. Despite a large adaptive capacity, society may not take the necessary steps for implementing adaptation (Adger et al., 2007) and a comprehensive assessment of vulnerability, risks and uncertainties consequently needs to better address the specific adaptive capacity in the forest sector.

Very few European studies have assessed climate change vulnerability of the forest sector at regional scales. In northern Europe, vulnerability to climate change and extreme events 
increases the more dependent a region is on the employment generated by the forest sector (Lundmark et al., 2008). Keskitalo (2008) studied forest sector vulnerability in a small case study in Northern Sweden and stressed the importance of globalisation and other socio-economic changes superseding vulnerability to climate change. Similar results were shown for vulnerability of reindeer husbandry to climate change (Rees et al., 2008). Seidl et al. (in press) found mountain forests in Austria highly vulnerable to climatic change under the current management regime, particularly in the second half of the 21st century. Sustainable forest management indicators such as productivity and forest health decreased significantly (i.e. high sensitivity) in combination with stable or moderately decreasing ecological and economic system states (i.e. adaptive capacity).

Other regional scale vulnerability assessments of the European forest sector are missing to date. Such studies, however, would be particularly valuable amending continental scale analysis as vulnerability is strongly scale dependent (O'Brien et al., 2004). From our assessment of potential impacts and adaptive capacity in European regions we have to conclude that especially the Mediterranean region is highly vulnerable to climate change. Considerable risks occur also in all other regions and therefore the assessment of regional vulnerability to climate change including quantified risks and opportunities requires more investigation and constitutes a clear research need.

The remaining knowledge gaps, both with regard to systems understanding and assessment methodology, are crucial to the design of adaptive management strategies and essential to the sustainable management of European forest resources under climate change. Regional vulnerability assessments can serve as basis for targeted adaptation strategies (Füssel and Klein, 2006). Yet we need a better understanding of aspects such as adaptive capacity, including also the operational level. Vulnerability research needs to be interdisciplinary, covering not only ecological, but also economic and social perspectives. A broad research agenda ranging from the improvement of regional climate change projections to strengthening the understanding of tree responses and adaptive capacity of the forest sector is required. This should, to extent possible, be harmonized with existing and improved monitoring networks and foster the development of projection tools. Such an integrated research agenda could provide information at all levels of decision making, from policy development to the management unit.

While the majority of climate change impacts are likely to be negative - especially in the long-term - it should not be forgotten that some opportunities arise as well (e.g. improved tree growth, northward expansion of potential distribution of some tree species, potentially more favourable conditions for summer recreation in mountainous regions). Utilizing such benefits, even if they are only of temporary nature, could increase the adaptive capacity of the sector and support long-term adaptation and innovation to better cope with climate change.

The vast majority of literature on climate change impacts and vulnerability of the forest sector is of theoretical nature and a huge gap between theory and practice can be observed. Potential impacts are often far away from realistic projections. A good example is projected impacts on biodiversity. Most existing studies rely on environmental envelop approaches which suggest that there will be a shift in the natural species composition from coniferous dominated forests towards broadleaved species (e.g. Thuiller et al., 2006). However, it is still less understood how fast species will retrieve from areas that are no longer matching their natural ecological niche. As the majority of European forests is intensively managed, management effects will strongly influence the transition by either maintaining economically important species outside their natural range (this has been the case with
Norway spruce, Spiecker et al., 2004) or by supporting the regeneration of new target species. Another shortcoming is that effects of intensified disturbance regimes are often not included in current impact assessments, whereas in reality reactions of forest managers are often triggered by disturbance induced impacts.

There will be a continuous challenge to provide scientific knowledge in a form that also local managers and policy makers can utilize. But despite of two decades of quite active research, there are currently still many weak areas, where potential impacts are not well understood. More importantly, understanding of adaptive capacity and regional vulnerability to climate change in European forests is not well developed and requires more focussed research efforts.

\section{Acknowledgements}

This research is based on a study commissioned by the European Directorate General for Agriculture and Rural Development "Impacts of Climate Change on European Forests and Options for Adaptation" (AGRI-2007-G4-06). We would like to thank Maria Fuentes and the project Steering Group for smooth co-operation and constructive guidance and Tim Green and Jarkko Heikkinen for their technical support.

\section{References}

Adger, W.N., Agrawala, S., Mirza, M.M.Q., Conde, C., O’Brien, K., Pulhin, J., Pulwarty, R. Smit, B., Takahashi, K., 2007. Assessment of adaptation practices, options, constraints and capacity. In: Parry, M.L., Canziani, O.F., Palutikof, J.P., Linden, P.J.V.D., Hanson, C.E. (Eds.), Climate Change 2007: Impacts, Adaptation and Vulnerability. Contribution of Working Group II to the Fourth Assessment Report of the Intergovernmental Panel on Climate Change. Cambridge University Press, Cambridge, UK, pp. 717-743.

Ainsworth, E.A., Long, S.P., 2005. What have we learned from 15 years of free-air $\mathrm{CO}_{2}$ enrichment (FACE)? A meta-analytic review of the responses of photosynthesis, canopy properties and plant production to rising $\mathrm{CO}_{2}$. New Phytologist 165 351-372.

Aitken, S.N., Yeaman, S., Holliday, J.A., Wang, T., Curtis-McLane, S., 2008. Adaptation, migration or extirpation: climate change outcomes for tree populations. Evolutionary Applications 1, 95-111.

Aptroot, A., van Herk, C.M., 2007. Further evidence of the effects of global warming on lichens, particularly those with Trentepohlia phycobionts. Environmental Pollution 146, 293-298.

Asshoff, R., Zotz, G., Korner, C., 2006. Growth and phenology of mature temperate forest trees in elevated $\mathrm{CO}_{2}$. Global Change Biology 12, 848-861.

Auer, I., Böhm, R., Jurkovic, A., Lipa, W., Orlik, A., Potzmann, R., Schöner, W., Ungersböck, M., Matulla, C., Briffa, K., Jones, P., Efthymiadis, D., Brunetti, M. Nanni, T., Maugeri, M., Mercalli, L., Mestre, O., Moisselin, J., Begert, M., MüllerWestermeier, G., Kveton, V., Bochnicek, O., Stastny, P., Lapin, M., Szalai, S. Szentimrey, T., Cegnar, T., Dolinar, M., Gajic-Capka, M., Zaninovic, K., Majstorovic, Z., Nieplova, E., 2007. HISTALP - Historical instrumental climatological surface time series of the Greater Alpine Region. International Journal of Climatology 27, 17-46.

Ayres, M.P., Lombardero, M.J., 2000. Assessing the consequences of global change for forest disturbance from herbivores and pathogens. The Science of the Total Environment 262, 263-286.

Baier, P., Pennerstorfer, J., Schopf, A., 2007. Phenips - A comprehensive phenology model of Ips typographus (L.) (Col. Scolytidae) as a tool for hazard rating of bark beetle infestation. Forest Ecology and Management 249, 171-186.

Balci, Y., Halmschlager, E., 2003. Incidence of Phytophthora species in oak forests in Austria and their possible involvement in oak decline. Forest Pathology 33 157-174.

Bale, J.S., Masters, G.J., Hodkinson, I.D., Awmack, C., Bezemer, T.M., Brown, V.K., Butterfield, J., Buse, A., Coulson, J.C., Farrar, J., Good, J.E.G., Harrington, R., Hartley, S., Jones, H.T., Lindroth, R.L., Press, M.C., Symrnioudis, I., Watt, A.D. Whittaker, J.B., 2002. Herbivory in global climate change research: direct effects of rising temperature on insect herbivores. Global Change Biology 8, 1-16.

Battisti, A., 2004. Forests and climate change - lessons from insects. Forest 1, 17-24.

Battisti, A., Stastny, M., Buffo, E., Larsson, S., 2006. A rapid altitudinal range expansion in the pine processionary moth produced by the 2003 climatic anomaly. Global Change Biology 12, 662-671.

Battisti, A., Stastny, M., Netherer, S., Robinet, C., Schopf, A., Roques, A., Larsson, S., 2005. Expansion of geographic range in the pine processionary moth caused by increased winter temperatures. Ecological Applications 15, 2084-2096.

Bergh, J., Freeman, M., Sigurdsson, B., Kellomaki, S., Laitinen, K., Niinisto, S., Peltola, H., Linder, S., 2003. Modelling the short-term effects of climate change on the productivity of selected tree species in Nordic countries. Forest Ecology and Management 183, 327-340. 
Bernhold, A., 2008. Resistance of introduced Pinus contorta and native P. sylvestris to Gremmeniella abietina (LTT, European race) in Sweden. In, International Conference on Adaptation of Forests and Forest Management to Changing Climate with Emphasis on Forest Health: A Review of Science, Policies and Practices, Umea, Sweden.

Birks, H.J.B., 1989. Holocene isochrone maps and patterns of tree spreading in the British Isles. Journal of Biogeography 16, 503-540.

Bokhorst, S., Bjerke, J.W., Bowles, F.W., Melillo, J., Callaghan, T.V., Phoenix, G.K., 2008. Impacts of extreme winter warming in the sub-Arctic: growing season responses of dwarf shrub heathland. Global Change Biology 14, 2603-2612.

Bolli, J.C., Rigling, A., Bugmann, H., 2007. The influence of changes in climate and land-use on regeneration dynamics of Norway spruce at the treeline in the swiss alps. Silva Fennica 41, 55-70.

Bossdorf, O., Richards, C.L., Pigliucci, M., 2008. Epigenetics for ecologists. Ecology Letters $11,106-115$.

Brewer, S., Cheddadi, R., De Beaulieu, J.L., Reille, M., 2002. The spread of deciduous Quercus throughout Europe since the last glacial period. Forest Ecology and Management 156, 27-48

Briceño-Elizondo, E., Garcia-Gonzalo, J., Peltola, H., Matala, J., Kellomäki, S., 2006. Sensitivity of growth of Scots pine, Norway spruce and silver birch to climate change and forest management in boreal conditions. Forest Ecology and Management 232, 152-167.

Büntgen, U., Frank, D.C., Kaczka, R.J., Verstege, A., Zwijackz-Kozica, T., Esper, J., 2007. Growth responses to climate in a multi-species tree-ring network in the Western Carpathian Tatra Mountains, Poland and Slovakia. Tree Physiology 27, 689-702.

Callaghan, T.V., Björn, L.O., Chernov, Y., Chapin, T., Christensen, T.R., Huntley, B., Ims, R.A., Johansson, M., Jolly, D., Jonasson, S., Matveyeva, N., Panikov, N., Oechel, W., Shaver, G., Elster, J., Henttonen, H., Laine, K., Taulavuori, K., Taulavuori, E., Zöckler, C., 2004. Biodiversity, distributions and adaptations of arctic species in the context of environmental change. Ambio 33, 404-417.

Camarero, J.J., Gutierrez, E., 2004. Pace and pattern of recent treeline dynamics: response of ecotones to climatic variability in the Spanish Pyrenees. Climatic Change 63, 181-200

Cannon, R.J.C., 1998. The implications of predicted climate change in the UK, with emphasis on non-indigenous species. Global Change Biology 4, 785-796.

Certini, G., 2005. Effects of fire on properties of forest soils: a review. Oecologia 143, $1-10$.

Christensen, J.H., Hewitson, B., Busuioc, A., Chen, A., Gao, X., Held, I., Jones, R., Kolli, R.K., Kwon, W.-T., Laprise, R., Rueda, V.M., Mearns, L., Menéndez, C.G., Räisänen, J., Rinke, A., Sarr, A., Whetton, P., 2007. Regional climate projections. In: Solomon, S., Qin, D., Manning, M., Chen, Z., Marquis, M., Averyt, K.B., Tignor, M., Miller, H.L. (Eds.), Climate Change 2007: The Physical Science Basis. Contribution of Working Group I to the Fourth Assessment Report of the Intergovernmental Panel on Climate Change. Cambridge University Press, Cambridge, United Kingdom/New York, NY, USA, pp. 847-940.

Ciais, P., Reichstein, M., Viovy, N., Granier, A., Ogee, J., Allard, V., Aubinet, M., Buchmann, N., Bernhofer, C., Carrara, A., Chevallier, F., De Noblet, N., Friend, A.D., Friedlingstein, P., Grunwald, T., Heinesch, B., Keronen, P., Knohl, A., Krinner, G., Loustau, D., Manca, G., Matteucci, G.M.F., Ourcival, J.M., Papale, D., Pilegaard, K., Rambal, S., Seufert, G., Soussana, J.F., Sanz, M.J., Schulze, E.D., Vesala, T., Valentini, R., 2005. Europe-wide reduction in primary productivity caused by the heat and drought in 2003. Science 437, 529-533.

Colombaroli, D., Marchetto, A., Tinner, W., 2007. Long-term interactions between Mediterranean climate, vegetation and fire regime at Lago di Massaciuccoli (Tuscany, Italy). Journal of Ecology 95, 755-770.

Delitti, W., Ferran, A., Trabaud, L., Vallejo, V.R., 2005. Effects of fire recurrence in Quercus coccifera L. shrublands of the Valencia Region (Spain). I. Plant composition and productivity. Plant Ecology 177, 57-70.

Desprez-Loustau, M., Marcais, B., Nageleisen, L., Piou, D., Vannini, A., 2006. Interactive effects of drought and pathogens in forest trees. Annals of Forest Science $63,597-612$

Desprez-Loustau, M., Robin, C., Reynaud, G., Déqué, M., Badeau, V., Piou, D., Husson, C., Marcais, B., 2007. Simulating the effects of a climate-change scenario on the geographical range and activity of forest-pathogenic fungi. Canadian Journal of Plant Pathology 29, 101-120.

Eggers, J., Lindner, M., Zaehle, S., Zudin, S., Liski, J., 2008. Impact of changing wood demand, climate and land use on European forest resources and carbon stocks during the 21st century. Global Change Biology 14, 2288-2303.

Engesser, R., Forster, B., Meier, F., Odermatt, O., 2005. Waldschutzsituation 2004 in der Schweiz. Allg. Forst Z. Waldwirtsch. Umweltvorsorge 07/2005, 379-381.

Field, C.B., Jackson, R.B., Mooney, H.A., 1995. Stomatal responses to increased $\mathrm{CO}_{2}$ : implications from the plants to the global scale. Plant, Cell and Environment 18, 1214-1225.

Flannigan, M.D., Stocks, B.J., Wotton, B.M., 2000. Climate change and forest fires. Science of the Total Environment 262, 221-229.

Fuhrer, J., Beniston, M., Fischlin, A., Frei, C., Goyette, S., Jasper, K., Pfister, C., 2006. Climate risks and their impact on agriculture and forests in Switzerland. Climatic Change 79, 79-102.

Füssel, H.-M., Klein, R.J.T., 2006. Climate change vulnerability assessments: an evolution of conceptual thinking. Climatic Change 75, 301-329.

Gange, A.C., Gange, E.G., Sparks, T.H., Boddy, L., 2007. Rapid and Recent Changes in Fungal Fruiting Patterns. Science 316, 71.

Garcia-Gonzalo, J., Peltola, H., Briceño-Elizondo, E., Kellomäki, S., 2007a. Changed thinning regimes may increase carbon stock under climate change: a case study from a Finnish boreal forest. Climatic Change 81, 431-454.
Garcia-Gonzalo, J., Peltola, H., Briceño-Elizondo, E., Kellomäki, S., 2007b. Effects of climate change and management on timber yield in boreal forests, with economic implications: a case study. Ecological Modelling 209, 220-234.

Geßler, A., Keitel, C., Kreuzwieser, J., Matyssek, R., Seiler, W., Rennenberg, H., 2007. Potential risks for European beech (Fagus sylvatica L.) in a changing climate. Trees - Structure and Function 21, 1-11.

Glenz, C., Schlaepfer, R.I.I., Kienast, F., 2006. Flooding tolerance of Central European tree and shrub species. Forest Ecology and Management 235, 1-13.

Grace, J., Berninger, F., Nagy, L., 2002. Impacts of climate change on the tree line. Annals of Botany 90, 537-544.

Granier, A., Reichstein, M., Bréda, N., Janssens, I.A., Falge, E., Ciais, P., Grünwald, T., Aubinet, M., Berbigier, P., Bernhofer, C., Buchmann, N., Facini, O., Grassi, G., Heinesch, B., Ilvesniemi, H., Keronen, P., Knohl, A., Köstner, B., Lagergren, F., Lindroth, A., Longdoz, B., Loustau, D., Mateus, J., Montagnani, L., Nys, C., Moors, E., Papale, D., Peiffer, M., Pilegaard, K., Pita, G., Pumpanen, J., Rambal, S., Rebmann, C., Rodrigues, A., Seufert, G., Tenhunen, J., Vesala, T., Wang, Q., 2007. Evidence for soil water control on carbon and water dynamics in European forests during the extremely dry year: 2003. Agricultural and Forest Meteorology 143, 123-145.

Hänninen, H., 2006. Climate warming and the risk of frost damage to boreal forest trees: identification of critical ecophysiological traits. Tree Physiology 26, 889898

Hansen, J., Ruedy, R., Sato, M., Lo, K., 2006. GISS Surface Temperature Analysis. Global Temperature Trends: 2005 Summation. NASA Goddard Institute for Space Studies and Columbia University Earth Institute, New York, NY 10025, USA.

Hemery, G.E., Russell, K., 2006. Advances in walnut breeding and culture in the United Kingdom. Acta Horticulturae 705, 95-101.

Hlásny, T., Turcány, M., 2009. Insect pests as climate change driven disturbances in forest ecosystems. In: Strelcová, K., Matyas, C., Kleidon, A., Lapin, M., Matejka, F., Blazenec, M., Škvarenina, J., Holecy, J. (Eds.), Bioclimatology and Natural Hazards. Springer, Berlin.

Hodar, J.A., Zamora, R., 2004. Herbivory and climatic warming: a Mediterranean outbreaking caterpillar attacks a relict, boreal pine species. Biodiversity and Conservation 13, 493-500.

Huberty, A.F., Denno, R.F., 2004. Plant water stress and its consequences for herbivorous insects: a new synthesis. Ecology 85, 1383-1398.

Hungate, B.A., Dukes, J.S., Shaw, M.R., Luo, Y., Field, C.B., 2003. Nitrogen and Climate Change. Science 302, 1512-1513.

Hunter, D., 2001. Effects of elevated atmospheric carbon dioxide on insect-plant interactions. Agricultural and Forest Entomology 3, 153-159.

Jandl, R., Herman, F., Smidt, S., Butterbach-Bahl, K., Englisch, M., Katzensteiner, K., Lexer, M., Strebl, F., Zechmeister-Boltenstern, S., 2008. Nitrogen dynamics of a mountain forest on dolomitic limestone - a scenario-based risk assessment. Environmental Pollution 155, 512-516.

Jump, A.S., Hunt, J.M., Peñuelas, J., 2006. Rapid climate change-related growth decline at the southern range edge of Fagus sylvatica. Global Change Biology $12,2163-2174$.

Kahle, H.-P., 1994. Modellierung der Zusammenhänge zwischen der Variation von klimatischen Elementen des Wasserhaushaltes und dem Radialzuwachs von Fichten (Picea abis (L.) Karst.) aus Hochlagen des Südschwarzwaldes. Eine standortbezogene dendroökologische Untersuchung unter besonderer Berücksichtigung von Trockenstreß. In, Forstwissenschaftliche Fakultät der Universität Freiburg/Breisgau. Albert-Ludwig-Universität Freiburg, Freiburg, p. 185

Kahle, H.P., Karjalainen, T., Schuck, A., Ågren, G.I., Kellomäki, S., Mellert, K.H., Prietzel, J., Rehfuess, K.E., Spiecker, H. (Eds.), 2008. Causes and Consequences of Forest Growth Trends in Europe - Results of the RECOGNITION Project. EFI Research Report 21, Brill Leiden, Boston, Köln.

Karolewski, P., Grzebyta, J., Oleksyn, J., Giertych, M.J., 2007. Effects of temperature on larval survival rate and duration of development in Lymantria monacha (L.) on needles of Pinus sylvestris (L.) and in L. dispar (L.) on leaves of Quercus robur (L.). Polish Journal of Ecology 55, 595-600.

Kauserud, H.V., Stige, L.C., Vik, J.O., Okland, R.H., Hoiland, K., Stenseth, N.C., 2008. Mushroom fruiting and climate change. Proceedings of the National Academy of Sciences U.S.A. 105, 3811-3814.

Kellomäki, S., Karjalainen, T., Väisänen, H., 1997. More timber from boreal forests under changing climate? Forest Ecology and Management 94, 195-208.

Kellomäki, S., Väisänen, H., 1997. Modelling the dynamics of the forest ecosystem for climate change studies in the boreal conditions. Ecological Modelling 97, $121-140$.

Kellomäki, S., Wang, K.Y., 1996. Photosynthetic responses to needle water potentials in Scots pine after a four-year exposure to elevated $\mathrm{CO}_{2}$ and temperature. Tree Physiology 16, 765-772.

Kelly, P.M., Adger, W.N., 2000. Theory and practice in assessing vulnerability to climate change and facilitating adaptation. Climatic Change 47, 325-352.

Keskitalo, E.C.H., 2008. Vulnerability and adaptive capacity in forestry in northern Europe: a Swedish case study. Climatic Change 87, 219-234.

Kienast, F., Wildi, O., Brzeziecki, B., 1998. Potential impacts of climate change on species richness in mountain forests - An ecological risk assessment. Biological Conservation 83, 291-305.

Kirschbaum, M.U., 1995. The temperature dependence of soil organic matter decomposition, and the effect of global warming on soil organic C storage. Soil Biology and Biochemistry 27, 753-760.

Klanderud, K., 2005. Climate change effects on species interactions in an alpine plant community. Journal of Ecology 93, 127-137. 
König, A.O., 2005. Provenance research: evaluating the spatial pattern of genetic variation. In: Geburek, T., Turok, J. (Eds.), Conservation and Management of Forest Genetic Resources in Europe. Arbora Publishers, Zvolen, Slovakia, pp. 275-333.

Kramer, K., Vreugdenhil, S.J., van der Werf, D.C., 2008. Effects of flooding on the recruitment, damage and mortality of riparian tree species: a field and simulation study on the Rhine floodplain. Forest Ecology and Management 255 , 3893-3903.

Krehan, H., Steyrer, G., 2004. Borkenkäferkalamität 2003. In, Forstschutz aktuell Bundesamt und Forschungszentrum für Wald (BFW), pp. 10-12.

Lasch, P., Badeck, F.W., Lindner, M., Suckow, F., 2002a. Sensitivity of simulated forest growth to changes in climate and atmospheric $\mathrm{CO}_{2}$. Forstwissenschaftliches Centralblatt 121, 155-171

Lasch, P., Lindner, M., Erhard, M., Suckow, F., Wenzel, A., 2002b. Regional impact assessment on forest structure and functions under climate change - the Brandenburg case study. Forest Ecology and Management 162, 73-86.

Lenormand, T., 2002. Gene flow and the limits to natural selection. Trends in Ecology and Evolution 17, 183-189.

Lettens, S., Orshoven, J.V., Perrin, D., Wesemael, B.V., Muys, B., 2008. Organic carbon stocks and stock changes of forest biomass in Belgium derived from forest inventory data in a spatially explicit approach. Annals of Forest Science 65 , 604-1604.

Lexer, M.J., Hönninger, K., Scheifinger, H., Matulla, C., Groll, N., Kromp-Kolb, H. Schadauer, K., Starlinger, F., Englisch, M., 2002. The sensitivity of Austrian forests to scenarios of climatic change: a large-scale risk assessment based on a modified gap model and forest inventory data. Forest Ecology and Management $162,53-72$

Lindroth, A., Lagergren, F., Grelle, A., Klemedtsson, L., Langvall, O., Weslien, P. Tuulik, J., 2009. Storms can cause Europe-wide reduction in forest carbon sink Global Change Biology 15, 346-355.

Lloret, F., Penuelas, J., Estiarte, M., 2004. Experimental evidence of reduced diversity of seedlings due to climate modification in a Mediterranean-type community. Global Change Biology 10, 248-258.

Lortie, C.J., Brooker, R.W., Choler, P., Kikvidze, Z., Michalet, R., Pugnaire, F.I., Callaway, R., 2004. Rethinking plant community theory. Oikos 107, 433-438.

Loustau, D., Bosc, A., Colin, A., Ogée, J., Davi, H., François, C., Dufrêne, E., Déqué, M., Cloppet, E., Arrouays, D., Le Bas, C., Saby, N., Pignard, G., Hamza, N., Granier, A. Bréda, N., Ciais, P., Viovy, N., Delage, F., 2005. Modeling climate change effects on the potential production of French plains forests at the sub-regional level. Tree Physiology 25, 813-823.

Lundmark, L., Pashkevich, A., Jansson, B., Wiberg, U., 2008. Effects of climate change and extreme events on forest communities in the European North. Climatic Change 87, 235-249.

Luo, Y., Su, B., Currie, W.S., Dukes, J.S., Finzi, A., Hartwig, U., Hungate, B., McMurtrie R.E., Oren, R., Parton, W.J., Pataki, D.E., Shaw, M.R., Zak, D.R., Field, C.B., 2004 Progressive nitrogen limitation of ecosystem responses to rising atmospheric carbon dioxide. BioScience 54, 731-739.

Madlung, A., Comai, L., 2004. The effect of stress on genome regulation and structure. Annals of Botany 94, 481-495.

Magnani, F., Mencuccini, M., Borghetti, M., Berbigier, P., Berninger, F., Delzon, S., Grelle, A., Hari, P., Jarvis, P.G., Kolari, P., Kowalski, A.S., Lankreijer, H., Law, B.E. Lindroth, A., Loustau, D., Manca, G., Moncrieff, J.B., Rayment, M., Tedeschi, V., Valentini, R., Grace, J., 2007. The human footprint in the carbon cycle of temperate and boreal forests. Nature 447, 849-851.

Mäkipää, R., Karjalainen, T., Pussinen, A., Kellomäki, S., 1999. Effects of climate change and nitrogen deposition on the carbon sequestration of a forest ecosystem in the boreal zone. Canadian Journal of Forest Research 29, 1490 1501.

Mäkipää, R., Karjalainen, T., Pussinen, A., Kukkola, M., 1998. Effects of nitrogen fertilization on carbon accumulation in boreal forests: model computations compared with the results of long-term fertilization experiments. Chemosphere $36,1155-1160$.

Maracchi, G., Sirotenko, O., Bindi, M., 2005. Impacts of present and future climate variability on agriculture and forestry in the temperate regions: Europe. Climatic Change 70, 117-135.

Maresi, G., Luchi, N., Pinzani, P., Pazzagli, M., Capretti, P., 2007. Detection of Diplodia pinea in asymptomatic pine shoots and its relation to the Normalized Insolation index. Forest Pathology 37, 272-280.

Martínez-Vilalta, J., López, B.C., Adell, N., Badiella, L., Ninyerola, M., 2008. Twentieth century increase of Scots pine radial growth in NE Spain shows strong climate interactions. Global Change Biology 14, 2868-2881.

Martínez de Aragón, J., Bonet, J.A., Fischer, C.R., Colinas, C., 2007. Productivity of ectomycorrhizal and selected edible saprotrophic fungi in pine forests of the pre-Pyrenees mountains, Spain: predictive equations for forest management of mycological resources. Forest Ecology and Management 252, 239-256.

Mattila, U., Nuutinen, T., 2007. Assessing the Incidence of Butt Rot in Norway Spruce in Southern Finland. Silva Fennica 41, 29-43.

Matyssek, R., Le Thiec, D., Löw, M., Dizengremel, P., Nunn, A.J., Häberle, K.H., 2006 Interactions between drought and $\mathrm{O}_{3}$ stress in forest trees. Plant Biology 8 , 11-17.

McCarthy, J.J., Canziani, O.F., Leary, N.A., Dokken, D.J., White, K.S.E., 2001. Climate Change 2001: Impacts, Adaptation, and Vulnerability. Cambridge University Press, UK, p. 1000.

McLaughlin, S.B., Wullschleger, S.D., Sun, G., Nosal, M., 2007. Interactive effects of ozone and climate on water use, soil moisture content and streamflow in a southern Appalachian forest in the USA. New Phytologist 174, 125-136.
Metzger, M., Schröter, D., Leemans, R., Cramer, W., 2008. A spatially explicit and quantitative vulnerability assessment of ecosystem service change in Europe. Regional Environmental Change 8, 91-107.

Moriondo, M., Good, P., Durao, R., Bindi, M., Giannakopoulos, C., Corte-Real, J., 2006. Potential impact of climate change on fire risk in the Mediterranean area. Climate Research 31, 85-95.

Müller-Starck, G., 1988. Genetic implications of environmental stress in adult forest stands. In: Scholz, F., Gregorius, H.R., Rudin, D. (Eds.), Genetic Effects of Air Pollutants in Forest Tree Populations. Springer Verlag, Berlin, Germany, pp. 127-142.

Nakicenovic, N., Alcamo, J., Davis, G., Vries, B.d., Fenhann, J., Gaffin, S., Gregory, K. Grübler, A., Jung, T.Y., Kram, T., Rovere, E.L.L., Michaelis, L., Mori, S., Morita, T. Pepper, W., Pitcher, H., Price, L., Riahi, K., Roehrl, A., Rogner, H.-H., Sankovski, A., Schlesinger, M., Shukla, P., Smith, S., Swart, R., Rooijen, S.v., Victor, N., Dadi, Z., 2000. IPCC Special Report on Emissions Scenarios (SRES).

Nierhaus-Wunderwald, D., 1996. Pilzkrankheiten in Hochlagen - Biologie und Befallsmerkmale Sonderdruck. Wald und Holz 77, 18-24.

Norby, R.J., Wullschleger, S.D., Gunderson, C.A., Johnson, D.W., Ceulemans, R., 1999. Tree responses to rising $\mathrm{CO}_{2}$ in field experiments: implications for the future forest. Plant, Cell and Environment 22, 683-714.

O’Brien, K., Sygna, L., Haugen, J.E., 2004. Vulnerable or resilient? A multi-scale assessment of climate impacts and vulnerability in Norway. Climatic Change $64,193-225$

OECD, 2006. Organisation for Economic Co-operation and Development. Domestic policy frameworks for adaptation to climate change in the water sector. Part I: Annex I countries, Part II: Non-Annex I countries, Paris.

Ogaya, R., Penuelas, J., Martinez-Vilalta, J., Mangiron, M., 2003. Effect of drought on diameter increment of Quercus ilex, Phillyrea latifolia, and Arbutus unedo in a holm oak forest of NE Spain. Forest Ecology and Management 180, 175-184.

Ogrin, D., 2007. Olive growing in Slovenian Istria and climatic limitations to its development. Moravian Geographical Reports 15, 34-40.

Okland, B., Bjornstad, O.N., 2003. Synchrony and geographical variation of the spruce bark beetle (Ips typographus) during a non-epidemic period. Population Ecology 45, 213-219.

Parmesan, C., 2006. Ecological and evolutionary responses to recent climate change. Annual Review of Ecology, Evolution and Systematics 37, 637-669.

Peltola, H., Gardiner, B., Kellomäki, S., Kolström, T., Lässig, R., Moore, J., Quine, C. Ruel, J.C., 2000. Wind and other abiotic risks to forests. Forest Ecology and Management 135, 1-2.

Peñuelas, J., Boada, M., 2003. A global change-induced biome shift in the Montseny mountains (NE Spain). Global Change Biology 9, 131-140.

Peñuelas, J., Ogaya, R., Boada, M., Jump, A.S., 2007. Migration, invasion and decline: changes in recruitment and forest structure in a warming-linked shift of European beech forest in Catalonia (NE Spain). Ecography 30, 829-837.

Phoenix, G.K., Gwynn-Jones, D., Callaghan, T.V., Sleep, D., Lee, J.A., 2001. Effects of global change on a sub-arctic heath: effects of enhanced UV-B radiation and increased summer precipitation. Journal of Ecology 89, 256-267.

Picon, C., Guehl, J.M., Aussenac, G., 1996. Growth dynamics, transpiration and water-use efficiency in Quercus robur plants submitted to elevated $\mathrm{CO}_{2}$ and drought. Annales des Sciences Forestieres 53, 431-446.

Rambal, S., Ourcival, J.M., Joffre, R., Mouillot, F., Nouvellon, Y., Reichstein, M., Rocheteau, A., 2003. Drought controls over conductance and assimilation of a Mediterranean evergreen ecosystem: scaling from leaf to canopy. Global Change Biology 9, 1813-1824.

Rebetez, M., Dobbertin, M., 2004. Climate change may already threaten Scots pine stands in the Swiss Alps. Theoretical and Applied Climatology 79, 1-9.

Reed, D., Nagel, L., 2003. Carbon pools and storage along a temperate to boreal transect in Northern Scots pine (Pinus sylvestris) forests. Polish Journal of Ecology 51, 545-552.

Rees, W.G., Stammler, F.M., Danks, F.S., Vitebsky, P., 2008. Vulnerability of European reindeer husbandry to global change. Climatic Change 87, 199-217.

Reid, H., 2006. Climate Change and Biodiversity in Europe. Conservation and Society $4,84-101$.

Rennenberg, H., Loreto, F., Polle, A., Brilli, F., Fares, S., Beniwal, R.S., Gessler, A., 2006 Physiological responses of forest trees to heat and drought. Plant Biology 8 556-571.

Rivas-Martínez, S., Penas, A., Díaz, T.E., 2004. Cartographic Service, University of León, Spain.

Robinet, C., Baier, P., Pennerstorfer, J., Schopf, A., Roques, A., 2007. Modelling the effects of climate change on the potential feeding activity of Thaumetopoea pityocampa (Den. \& Schiff.) (Lep., Notodontidae) in France. Global Ecology and Biogeography 16, 460-471.

Rouault, G., Candau, J.N., Lieutier, F., Nageleisen, L.M., Martin, J.C., Warzée, N., 2006 Effects of drought and heat on forest insect populations in relation to the 2003 drought in Western Europe. Annals of Forest Science 63, 613-624.

Saarinen, J., Tervo, K., 2006. Perceptions and adaptation strategies of the tourism industry to climate change: the case of Finnish nature-based tourism entrepreneurs. International Journal of Innovation and Sustainable Development 1 , 214-228.

Saxe, H., Cannell, M.G.R., Johnsen, B., Ryan, M.G., Vourlitis, G., 2001. Tree and forest functioning in response to global warming. New Phytologist 149, 369-399.

Saxe, H., Ellsworth, D.S., Heath, J., 1998. Tree and forest functioning in an enriched $\mathrm{CO}_{2}$ atmosphere. New Phytologist 139, 395-436.

Schär, C., Jendritzky, G., 2004. Hot news from summer 2003. Nature 432, 559-560.

Schelhaas, M.J., Nabuurs, G.J., Schuck, A., 2003. Natural disturbances in the European forests in the 19th and 20th centuries. Global Change Biology 9, 1620-1633. 
Schröter, D., Cramer, W., Leemans, R., Prentice, I.C., Araújo, M.B., Arnell, N.W., Bondeau, A., Bugmann, H., Carter, T.R., Gracia, C.A., De La Vega-Leinert, A.C., Erhard, M., Ewert, F., Glendining, M., House, J.I., Kankaanpää, S., Klein, R.J.T., Lavorel, S., Lindner, M., Metzger, M.J., Meyer, J., Mitchell, T.D., Reginster, I., Rounsevell, M., Sabate, S., Sitch, S., Smith, B., Smith, J., Smith, P., Sykes, M.T., Thonicke, K., Thuiller, W., Tuck, G., Zaehle, S., Zierl, B., 2005. Ecosystem service supply and vulnerability to global change in Europe. Science 310, 13331337.

Schumacher, S., Bugmann, H., 2006. The relative importance of climatic effects, wildfires and management for future forest landscape dynamics in the Swiss Alps. Global Change Biology 12, 1435-1450.

Schutz, J.P., Gotz, M., Schmid, W., Mandallaz, D., 2006. Vulnerability of spruce (Picea abies) and beech (Fagus sylvatica) forest stands to storms and consequences for silviculture. European Journal of Forest Research 125, 291-302.

Seidl, R., Rammer, W., Jäger, D., Lexer, M.J., 2008a. Impact of bark beetle (Ips typographus L.) disturbance on timber production and carbon sequestration in different management strategies under climate change. Forest Ecology and Management 265, 209-220

Seidl, R., Rammer, W., Lasch, P., Badeck, F.W., Lexer, M.J., 2008b. Does conversion of even-aged, secondary coniferous forests affect carbon sequestration? A simulation study under changing environmental conditions. Silva Fennica 42, 369386.

Seidl, R., Rammer, W., Lexer, M.J., in press. Climate change vulnerability of sustainable forest management in the Eastern Alps. Climatic Change.

Seidl, R., Schelhaas, M.-., Lindner, M., Lexer, M.J., 2009. Modelling bark beetle disturbances in a large scale forest scenario model to assess climate change impacts and evaluate adaptive management strategies. Regional Environmental Change 9, 101-119.

Senn, J., 1999. Tree mortality caused by Gremmeniella abietina in a subalpine afforestation in the central Alps and its relationship with duration of snow cover. European Journal of Forest Pathology 29, 65-74.

Skrøppa, T., Nikkanen, T., Ruotsalainen, S., Johnsen, O., 1994. Effects of sexual reproduction at different latitudes on performance of the progeny of Picea abies. Silvae Genetica 43, 297-303.

Skvarenina, J., Krizova, E., Tomlain, J., 2004. Impact of the climate change on the water balance of altitudinal vegetation stages in Slovakia. Ekologia Bratislava 23, 13-29.

Smouse, P.E., Sork, V.L., 2004. Measuring pollen flow in forest trees: an exposition of alternative approaches. Forest Ecology and Management 197, 21-38.

Solomon, A.M., 1997. Natural migration rates of trees: global terrestrial carbon cycle implications. In: Huntley, B., Cramer, W., Morgan, A.V., Prentice, H.C., Allen, J.R.M. (Eds.), Past and Future Rapid Environmental Changes: The Spatial and Evolutionary Responses of Terrestrial Biota. Springer, Berlin, pp. 455-468.

Spiecker, H., Hansen, J., Klimo, E., Skovsgaard, J.P., Sterba, H., Teuffel, K.V. (Eds.), 2004. Norway Spruce Conversion - Options and Consequences. EFI Research Report 18. Brill, Leiden/Boston/Köln, p. 320.

Svensson, M., Jansson, P.E., Berggren Kleja, D., 2008. Modelling soil C sequestration in spruce forest ecosystems along a Swedish transect based on current conditions. Biogeochemistry 89, 95-119.

Tardif, J., Camarero, J.J., Ribas, M., Gutiérrez, E., 2003. Spatiotemporal variability in tree growth in the Central Pyrenees: climatic and site influences. Ecological Monographs 73, 241-257.

Theurillat, J.-P., Felber, F., Geissler, P., Gobat, J.-M., Fierz, M., Fischlin, A., Küpfer, P., Schüssel, A., Velluti, C., Zaho, G.-F., Williams, J., 1998. Sensitivity of plant and soil ecosystems of the Alps to climate change. In: Cebon, P., Dahinden, U., Davies, H.C., Imboden, D., Jaeger, C.C. (Eds.), Views form the Alps: Regional Perspectives on Climate Change. MIT Press, Cambridge, MA, pp. 225-308.

Thor, M., Stahl, G., Stenlid, J., 2005. Modelling root rot incidence in Sweden using tree, site and stand variables. Scandinavian Journal of Forest Research 20, 165-176.
Thuiller, W., Albert, C., Arau?jo, M.B., Berry, P.M., Cabeza, M., Guisan, A., Hickler, T., Midgley, G.F., Paterson, J., Schurr, F.M., Sykes, M.T., Zimmermann, N.E., 2008. Predicting global change impacts on plant species' distributions: future challenges. Perspectives in Plant Ecology, Evolution and Systematics 9, 137-152.

Thuiller, W., Lavorel, S., Sykes, M.T., Araújo, M.B., 2006. Using niche-based modelling to assess the impact of climate change on tree functional diversity in Europe? Diversity and Distributions 12, 49-60.

Thürig, E., Palosuo, T., Bucher, J., Kaufmann, E., 2005. The impact of windthrow on carbon sequestration in Switzerland: a model-based assessment. Forest Ecology and Management 210, 337-350.

Vanhanen, H., Veteli, T.O., Päivinen, S., Kellomäki, S., Niemela, P., 2007. Climate change and range shifts in two insect defoliators: gypsy moth and nun moth - A model study. Silva Fennica 41, 621-638.

Veteli, T.O., Lahtinen, A., Repo, T., Niemelä, P., Varama, M., 2005. Geographic variation in winter freezing susceptibility in the eggs of the European pine sawfly (Neodiprion sertifer). Agricultural and Forest Entomology 7, 115-120.

Vetter, M., Wirth, C., Böttcher, H., Churkina, G., Schulze, E.D., Wutzler, T., Weber, G., 2005. Partitioning direct and indirect human-induced effects on carbon sequestration of managed coniferous forests using model simulations and forest inventories. Global Change Biology 11, 810-827.

Virtanen, T., Neuvonen, S., Nikula, A., Varama, M., Niemelä, P., 1996. Climate change and the risk of Neodiprion sertifer outbreaks on Scots Pine. Silva Fennica 30, 169177

Volney, W.J.A., Fleming, R.A., 2000. Climate change and impacts of boreal forest insects. Agriculture, Ecosystems and Environment 82, 283-294.

Vucetich, J.A., Reed, D.D., Breymeyer, A., Degórski, M., Mroz, G.D., Solon, J., RooZielinska, E., Noble, R., 2000. Carbon pools and ecosystem properties along a latitudinal gradient in northern Scots pine (Pinus sylvestris) forests. Forest Ecology and Management 136, 135-145.

Wagner, F., Below, R., Klerk, P.D., Dilcher, D.L., Joosten, H., Kürschner, W.M. Visscher, H., 1996. A natural experiment on plant acclimation: lifetime stomatal frequency response of an individual tree to annual atmospheric $\mathrm{CO}_{2}$ increase. Proceedings of the National Academy of Sciences U.S.A. 21, 11705-11708.

Wallenius, T.H., 1999. Yield variations of some common wild berries in Finland in 1956-1996. Annales Botanici Fennici 36, 299-314.

Wargo, P.M., Harrington, T.C., 1991. Host stress and susceptibility. In: Shaw, C.G., Kile, G.A. (Eds.), Armillaria Root Disease. Forest Service, United States Department of Agriculture, Washington, D.C., pp. 88-101.

Wermelinger, B., 2004. Ecology and management of the spruce bark beetle Ips typographus - a review of recent research. Forest Ecology Management 202, 6782.

Westgarth-Smith, A.R., Leroy, S.A.G., Collins, P.E.F., Harrington, R., 2007. Temporal variations in English populations of a forest insect pest, the green spruce aphid (Elatobium abietinum), associated with the North Atlantic Oscillation and global warming. Quaternary International 173-174, 153-160.

Williams, D.W., Liebhold, A.M., 1995. Herbivorous insects and global change: potential changes in the spatial distribution of forest defoliator outbreaks. Journal of Biogeography 22, 665-671.

Wipf, S., Rixen, C., Mulder, C.P.H., 2006. Advanced snowmelt causes shift towards positive neighbour interactions in a subarctic tundra community. Global Change Biology 12, 1-11.

Wittig, V.E., Ainsworth, E.A., Naidu, S.L., Karnosky, D.F., Long, S.P., 2009. Quantifying the impact of current and future tropospheric ozone on tree biomass, growth, physiology and biochemistry: a quantitative meta-analysis. Global Change Biology 15, 396-424.

Wullschleger, S.D., Tschaplinski, T.J., Norby, R.J., 2002. Plant water relations at elevated $\mathrm{CO}_{2}$ - implications for water-limited environments. Plant, Cell and Environment 25, 319-331.

Zierl, B., Bugmann, H., 2007. Sensitivity of carbon cycling in the European Alps to changes of climate and land cover. Climatic Change 85, 195-212. 